\title{
Analysis of Economic Growth through Technological Advancement, Investment, Labor and Education
}

\author{
By \\ Nur Rifai ${ }^{\left.1^{*}\right)}$, Edy Yusuf Agung Gunanto ${ }^{2)}$, Joko Hadi Susilo ${ }^{3)}$ \\ 1) Master of Economics and Development Studies Diponegoro University, Indonesia \\ 2) Faculty of Economics and Business, University of Diponegoro \\ 3) Faculty of Economics, Bojonegoro University \\ ${ }^{*}$ Corresponding Author: rifaiekis@student.undip.ac.id
}

Submission: August 09, 2021; Accepted: September 23, 2021

\begin{abstract}
This study is aims to determine the variable influence of technological advances, investment, labor and education on economic growth in Central Java Province in 20162020, this research is conducted to provide the right economic growth model in accordance with the results of the study. This research is empirical research with quantitative approach. The data used in this study is secondary data from 35 districts/cities in Central Java Province in 2016-2020 so that the number of samples in the study is 175 samples. The data analysis technique in this study uses multiple linear regression analysis with the Fixed Effect model. This study found that the progress variable of technology, labor and education have a significant and positive influence on economic growth in Central Java Province. This study also found the investment variable had an insignificant effect on economic growth in Central Java Province.
\end{abstract}

Keywords: Economic Growth, Technological Advancement, Investment, Labor, Education.

\begin{abstract}
ABSTRAK
Penelitian ini bertujuan untuk mengetahui pengaruh variabel kemajuan teknologi, investasi, tenaga kerja dan pendidikan terhadap pertumbuhan ekonomi di Provinsi Jawa Tengah pada tahun 2016-2020, penelitian ini dilakukan untuk memberikan model pertumbuhan ekonomi yang tepat sesuai dengan hasil penelitian. Penelitian ini merupakan penelitian empiris, yaitu penelitian dengan adanya data-data lapangan sebagai sumber data utama dengan pendekatan kuantitatif. Data yang digunakan dalam penelitian ini berupa data sekunder yang didapat dari 35 kabupaten/kota di Provinsi Jawa Tengah tahun 2016-2020 sehingga jumlah sampel dalam penelitian adalah 175 sampel. Teknik analisis data dalam penelitian ini menggunakan analisis regresi linier berganda dengan model Fixed Effect. Hasil penelitian ini menunjukkan bahwa variabel kamajuan teknologi, tenaga kerja dan pendidikan mempunyai pengaruh signifikan dan positif terhadap pertumbuhan ekonomi di Provinsi Jawa Tengah. penelitian ini juga menemukan bahwa variabel investasi berpengaruh tidak signifikan terhadap pertumbuhan ekonomi di Provinsi Jawa Tengah.
\end{abstract}

Kata Kunci: Pertumbuhan Ekonomi, Kemajuan Teknologi, Investasi, Tenaga Kerja, Pendidikan

\section{INTRODUCTION}

According to Boediono (2009), economic growth is briefly defined as the process of increasing per capita output in the long run. By viewing at the definition, it means there are three emphasis that must 
be considered related to economic growth, namely: process, increase in output per capita, and longterm. Gradually, to understand the subject of economic growth, not only needed an understanding of the usefulness and truth contained in economic growth itself but also needed an understanding of the reasons why there are differences in income between regions (Rustiono, 2008). Many economists also said that economic growth can be considered to occur if it has a tendency (e.g. per capita output) sourced from the internal economic processes of a State, not from outside the temporary (Tarmizi, 2018). The following is the rate of economic growth in Java:

Table 1. Provincial PDRB Growth Rate in Java and DIY on a constant price basis 2016-2020 (\%)

\begin{tabular}{llllll}
\hline Province & $\mathbf{2 0 1 6}$ & $\mathbf{2 0 1 7}$ & $\mathbf{2 0 1 8}$ & $\mathbf{2 0 1 9}$ & $\mathbf{2 0 2 0}$ \\
\hline West Java & 5,66 & 5,33 & 5,64 & 5,07 & $-2,44$ \\
Central Java & $\mathbf{5 , 2 5}$ & $\mathbf{5 , 2 6}$ & $\mathbf{5 , 3 2}$ & $\mathbf{5 , 4 1}$ & $\mathbf{- 2 , 6 5}$ \\
DI Yogyakarta & 5,05 & 5,26 & 6,20 & 6,60 & $-2,69$ \\
East Java & 5,57 & 5,46 & 5,50 & 5,52 & $-2,39$ \\
\hline
\end{tabular}

Source: bps 2021 (Central Java Province in numbers 2021)

PDRB of Central Java Province over the last 5 years as seen in table 1.1 where the average growth rate of Central Java Province is highest at $5.41 \%$ compared to East Java, West Java, and Yogyakarta Province. In table 1.1 we can also see fluctuations in the growth rate of central Java Province which increased in 2016 to 2019 from 5.25\% in 2016 and to $5.41 \%$ in 2019 peaked in 2020 to $-2.65 \%$ due to the pandemic of covid-19. Compared with the growth in East Java and West Java, the increase of economic growth in Central Java has always been consistent in 2016 to 2019. It also happened to the economic growth of DI Yogyakarta. However, when compared to Central Java and DI Yogyakarta in 2020 during the COVID-19 pandemic, the province in Central Java experienced a more significant decline than DI Yogyakarta did. Based on this, this study takes the gap that there are factors affecting growth economy.

The success of a region or region can generally be seen in terms of economic growth (Arsyad, 2017). This has become one of the factors supporting the growth of the economy in a region (Chandra, 2015). This is done to see and measure the results and also the development of economic growth (Gamella et al, 2020); (Lubis, 2014). In a country, economic growth could be seen from the production of goods and services in the country (Ernita et al, 2013). Gross domestic product (GDP) is able to increase or decrease in the country (Purba \& Darmawan, 2018) it can be seen from the production process of goods and services in a country whether there is an increase or decrease (Lini \& Sasana, 2019). If there is an increase in GDP in one country, it shows that there is excitement or movement of economic growth, in the country and it will eventually be able to improve the welfare of the people in the country (Agustini \& Kurniasih, 2017).

Neo-classical growth theory was developed by Robert M. Solow (1956) and T.W. Swan (1956). The Solow-Swan model used elements of population growth, capital accumulation, technological advances (exogenous), and the magnitude of interacting outputs (Dhani, 2016). The main difference with Harrod Domar model is the inclusion of elements of technological advancement (Hapsari, 2018). In other mean, Solow-Swan used a production function model that allows substitution between capital (K) and labor (L) (Diana et al, 2017). The growth rate comes from three sources: capital accumulation, increased labor supply, and technological advancements (Hardinandar, 2019). This technology can be seen from the improvement of skills or advances in techniques so that productivity increases. In the Solow-Swan model, technological problems are considered functions of the time (Aulia \& Masbar, 2016). 


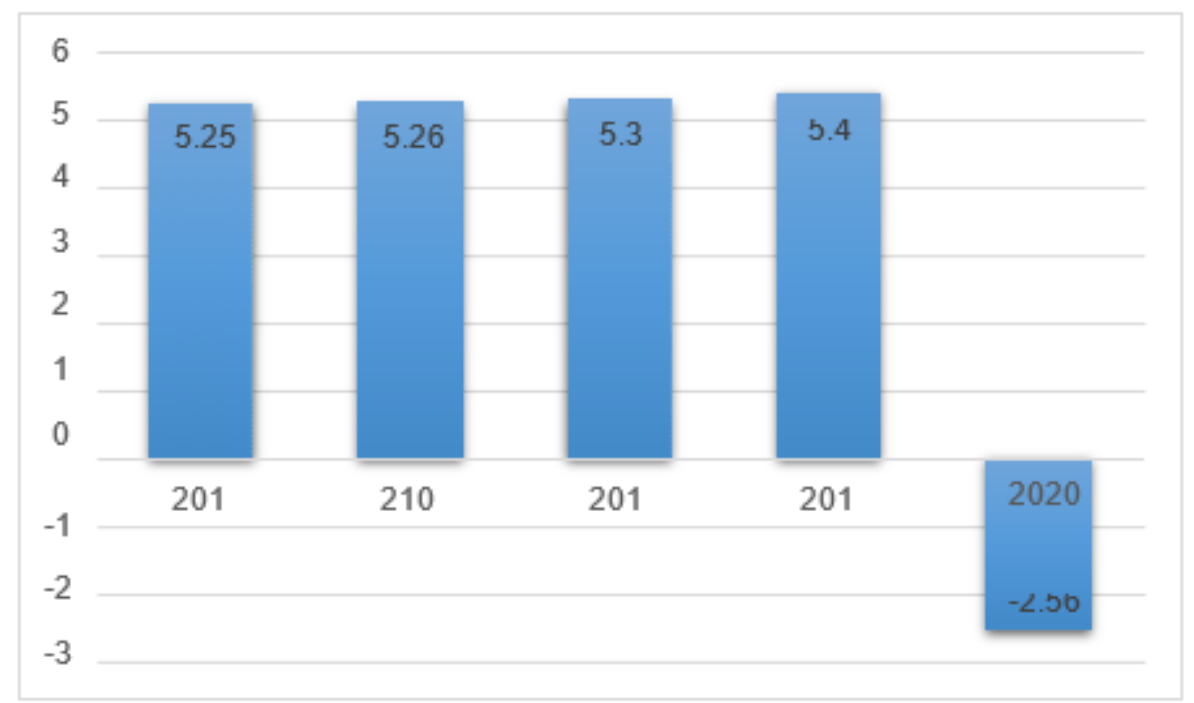

Figure 1. PDRB Growth Rate on the Basis of Constant Prices by Business Field in Central Java Province (percent) in $2016-2020$.

Source: BPS 2021 (Central Java Province in numbers 2021)

From the graph above central Java GDP actually always increased from 2016 - 2019 but in 2020 it experienced drastically decrease due to the pandemic of COVID-19. When compared to the number of residents in central Java province, it can be seen based on the following data:

Table 2. Population of central Java province in 2020

\begin{tabular}{ccccc}
\hline Gender & $\begin{array}{c}\text { Amount } \\
\text { (million persons) }\end{array}$ & $\begin{array}{c}\text { Working } \\
\text { (million } \\
\text { persons) }\end{array}$ & $\begin{array}{c}\text { Unemployed } \\
\text { (thousand } \\
\text { persons) }\end{array}$ & $\begin{array}{c}\text { Total } \\
\text { (million persons) }\end{array}$ \\
\hline Male & 19,4 & 11,9 & 525,4 & 39,3 \\
Female & 19,9 & 8,2 & 313,0 & \\
\hline
\end{tabular}

BPS Source: population and employment

Employment is a very important aspect to be reviewed. Countries with a very large population and limited supply of employment opportunities will undergo serious problems with the unemployment rate. The development occuring in the number of labor force (AK) cannot be separated from the rate of population growth in a region. Tjiptoherijanto (2001) stated that during the period 1997 - 1999 the number of labor force, Indonesia tends to increase, both working and looking for work. It was viewed between the number of people working and those looking for work, it turns out that the number of people who work is relatively larger than those looking for work, but the increase is much higher the increase in the population looking for work. Based on the perception of development, the population also serves as a labor force, there will be problems in the provision of employment. Thus, the increasing number of people in Indonesia from year to year while the number of available jobs can lead to competition among job seekers and threatened with a lack of opportunities for welfare fulfillment so it is feared to increase poverty. The main and fundamental problem in employment in Indonesia are the issue of low wages and high unemployment rate and the increasing number of people. This is caused the increase in new labor is much greater than the growth in employment being provided annually.

Labor growth compared to the availability of employment leads to high unemployment. According to Kelana (1997) investment is all expenditure of sources of funds to obtain capital expenditure. Investment as one of the very important factors in increasing the capacity of regional GDP. Characteristics of developing countries are lack of capital, lack of supply and low economic growth and technological backwardness. This can be seen from the high average cost of production 
but low labor productivity because of its unskilled workforce and simple capital equipment, this is clearly from the high capital output ratio, Indonesia is a developing country also cannot be separated from the above problems, therefore investment is one of the sources of financing that is needed to support development.

From the background description above, the researcher would like to present a paper on the Application of Solow Model in Spurring Economic Growth of central Java province. The purpose of this study is to analyze the influence of technological advances, investment, labor and education on economic growth in central Java Province. The objectives of this study are examining whether the Solow Swan model is able to spur economic growth in central Java with data on 35 city districts in central Java. Meanwhile the benefits of this research is as a source of input and reference for the Central Java Government in general and especially the city districts in central Java to improve economic growth through variable technological advances, investment, labor and education.

\section{Economic Development and Economic Growth}

Economic development is a multidimensional process including fundamental changes to social structure, community attitudes, and national institutions, while pursuing accelerated economic growth, tackling income inequality, and poverty alleviation (Todaro and Smith, 2006). Economic development covers various aspects such as economic, social, political and other aspects where the aspects synergize to achieve the success of development both at the central and regional levels. Therefore, participation of both the community and the government is required in achieving these goals. Another understanding of economic development according to Sukirno (2006) is a series of efforts in an economy to develop its economic activities so that more infrastructure is available, companies are getting more and more developed, the level of education is getting higher and technology is increasing. As an implication of this development is expected to increase employment opportunities and income levels of the community so that the standard of living of the community is improving.

Based on both understandings, it can be concluded that economic development is an effort made by the government both nationally and regionally for the welfare of its people. Economic growth is one of the benchmarks used to determine whether or not economic development in a country or region is successful. As one of the goals of economic development, economic growth shows the extent to which economic activity will generate additional income for the community in a certain period. Economic growth is characterized by an increase in GDP / PDRB regardless of whether the increase is greater or smaller than the rate of population growth or there is a change in economic structure or not. According to Todaro and Smith (2006), economic growth resources can include a variety of factors both economic and non-economic, but the main sources of economic growth are investments that are able to improve the quality of capital or physical resources, which can further increase the productivity of all resources through new discoveries, innovations and technological advances.

\section{Endogenous Growth Theory}

Endogenous growth theory explains that GNP growth is actually a natural consequence of long-term equilibrium. Endogenous growth theory has structural similarities to neoclassical theory, but differs greatly in terms of underlying assumptions and conclusions. A very significant theoretical difference stems from the release of neoclassical assumptions about declining marginal yields on capital investment, providing an opportunity for an increasing scale of yield in aggregate production and often focusing on the role of externalities in determining the rate of return on capital. It can be assumed that public and private sector investment in human resources results in an external economy and increased productivity that reverses the natural downward trend in yields, endogenous growth theory seeks to explain the existence of increasing yield scales and different long-term growth patterns between countries. Since technology still plays an important role in this theory, it is no longer necessary to explain long-term economic growth (Todaro and Smith, 2006).

In a simple model of economic growth, in general the definition of labor is defined as a homogeneous labor force. According to Lewis, a homogeneous and unskilled workforce is considered 
to be able to move from traditional to modern sectors smoothly and being in limited numbers. In such circumstances, the labor supply contains high elasticity. The increasing demand for labor (from the traditional sector) stems from the expansion of modern sector activities. Thus, one of the positive factors that affect economic growth is labor (Todaro and Smith, 2006). Through empirical studies conducted by Sodik (2007), Pujiati (2007) and Sumiyarti and Imamy (2005), the labor force had a positive and significant effect on economic growth.

Human Capital Theory is the theory underlying the importance of education for a person. The assumption used in this theory is that anyone are able to increase the income through improved education. Each additional expense one school year means on the one hand improving one's work ability and income level. However, on the other hand earning one school year means delaying income acceptance for one year in attending the school. The implication of human capital theory on economic growth is that by improving the quality of human resources through improving education in a country / region, it will create quality human resources that are responsive to changes in the future and they are able to create the latest innovations so that the production process can run more effectively (Simanjuntak, 2001).

\section{RESEARCH METHODOLOGY}

This research is empirical research conducted to determine the variables of technological progress, investment, labor and education to economic growth in central Java. This study used secondary data during the period 2016 to 2020 in 35 city districts in central Java so that the number of samples is 175 samples. Data collection in 2020 is certainly related to the COVID-19 pandemic, so this study will show the factors that affect economic growth in an aggregated manner. In connection with the research conducted, the operational definitions of variables used in this study are as follows:

1. Technological Progress (X1) referred to here is the index of construction skills for the period 2016-2020 35 city districts in central Java.

2. Investment (X2) referred to herein is the amount of investment both PMA and PMDN period 2016-2020 35 city districts in central Java

3. Labor (X3) referred to here is the number of (people) labor force during 2016-2020 35 city districts in central Java

4. Education (X4) referred to here is the number (of people) who completed college education in the period 2016-2020 35 city districts in central Java

This research was conducted in central Java province by collecting data on technological progress, investment, labor, education and Gross Regional Domestic Product (GDP) of central Java Province during 2016-2020 in 35 city districts in central Java. The reason for the election in central Java province is because it is considered to have sufficient data and information in order to answer the formulation of research problems, and facilitate research activities at once. In addition, the data shows that fluctuations in the growth rate of Central Java Province have increased which in 2016 to 2019 from $5.25 \%$ in 2016 and to $5.41 \%$ in 2019 peaking in 2020 to $-2.65 \%$ due to the pandemic. covid- 19 . When compared with the growth in East Java and West Java, the increase in economic growth in Central Java has always been consistent, meaning that from 2016 to 2019 there has always been an increase, this also happened to the economic growth of DI Yogyakarta. However, when compared to Central Java and DI Yogyakarta in 2020 during the COVID-19 pandemic, the province in Central Java experienced a more significant decline than DI Yogyakarta, based on this, this study takes the gap that there are factors that affect growth economy.

For research purposes is entirely data derived from secondary data, secondary data collection is carried out by direct collection and recording methods taken from various sources, where data is obtained through books, literatures, scientific reports and other official reports related to this research. The data comes from the Central Statistics Agency (BPS) of central Java province as well as other data sources that can support this research. The method of data analysis that will be used in this study is quantitative analysis method, which is an analysis technique that can be used to estimate parameters. Data analysis is done by statistically testing the variables that have been collected by supporting of the E Views 10 program. The results of the analysis are expected to be used to determine 
the magnitude of the influence of some free variables on bound variables. Data Panel Regression Analysis was used in this study. Panel data is collecting cross section data and in a certain period of time. Because the panel data is a combination of cross section and time series data, the number of observations become very large; $t$ takes its own techniques to overcome models that use panel data. Data collection techniques in this study are secondary data in the form of data on economic growth, technology, investment, labor and education.

\section{RESULTS AND DISCUSSION}

The model estimation test was conducted to find the most appropriate model to be used in econometric analysis. In the analysis of secondary data, it is not recommended to use validity and reliability tests, while the classical assumption test is carried out to support the results of model testing to identify hypotheses. The estimation of the model is tested in two ways, namely the Chow test and the Hausman test.

\section{Chow Test (Common Effect Model or Fixed Effect Model)}

With testing criteria:

1. HO: Model CEM better than model FEM. (prob $>0,05)$

2. H1: Model FEM better than model CEM. (prob $<0,05)$

Tabel 3. Chow test result

\begin{tabular}{lccc}
\hline Effects Test & Statistic & d.f. & Prob. \\
\hline Cross-section F & 164.343611 & $(34,136)$ & 0.0000 \\
Cross-section Chi-square & 654.449746 & 34 & 0.0000 \\
\hline
\end{tabular}

The results of the significance test which is a comparison between the common effect and fixed effect models can be seen from the analysis of Redundant Fixed Effect-LR. The results of the analysis showed the value of Prob. F of 0.00 . Due to Prob value. $\mathrm{F}<0.05$ then $\mathrm{HO}$ is rejected and $\mathrm{H} 1$ is received so that the more appropriate model estimate used is the fixed effect model.

\section{Hausman Test (Random Effect Model atau Fixed Effect Model)}

With testing criteria:

1. HO: REM model is better than FEM model. (prob $>0.05$ )

2. H1: FEM model is better than REM model. (prob $<0.05$ )

Tabel 4. Hausman result

\begin{tabular}{lccc}
\hline Test Summary & Chi-Sq. Statistic & Chi-Sq. d.f. & Prob. \\
\hline Cross-section random & 44.953279 & 4 & 0.0000 \\
\hline
\end{tabular}

The next method used is Hausman test. This test is done to determine a more appropriate model used between fixed effect and random effect models. Hausman's test results showed that prob values. Random cross section of 0.00 or less than 0.05 . It can be concluded that $\mathrm{H} 0$ is rejected which means that a more appropriate model is used is a fixed effect model. It means that the more appropriate model used to analyze this research is the fixed effect model.

\section{Data analysis}

The following are the results of the fixed effect model estimates for variable technological advances, investment, labor and education as independent variables as well as economic growth as dependent variables. 
Tabel 5. Hasil Fixed Effect Model

Fixed Effect Model (FEM) Dependent Variable: $Y$

\begin{tabular}{ccccc}
\hline Variable & Coefficient & Std. Error & t-Statistic & Prob. \\
\hline \hline C & -32.19698 & 7.183750 & -4.481918 & 0.0000 \\
X1 & 0.300264 & 0.064090 & 4.685057 & 0.0000 \\
X2 & $-1.19 \mathrm{E}-07$ & $1.36 \mathrm{E}-07$ & -0.874979 & 0.3831 \\
X3 & $5.37 \mathrm{E}-05$ & $9.88 \mathrm{E}-06$ & 5.429594 & 0.0000 \\
X4 & 0.588457 & 0.086969 & 6.766288 & 0.0000 \\
\hline
\end{tabular}

Effects Specification

Cross-section fixed (dummy variables)

\begin{tabular}{lrlr}
\hline \hline R-squared & 0.988851 & Mean dependent var & 37.71674 \\
Adjusted R-squared & 0.985735 & S.D. dependent var & 23.42616 \\
S.E. of regression & 2.797907 & Akaike info criterion & 5.089204 \\
Sum squared resid & 1064.647 & Schwarz criterion & 5.794499 \\
Log likelihood & -406.3053 & Hannan-Quinn criter. & 5.375292 \\
F-statistic & 317.4181 & Durbin-Watson stat & 1.359495 \\
Prob(F-statistic) & 0.000000 & & \\
\hline
\end{tabular}

The adjusted coefficient R-squared of the regression result is 0.988851 . The figures showed that $98.8 \%$ variation in economic growth output is explained by variables of technological progress, investment, labor and education while the rest is influenced by other variables not included in the model.

\section{F Test (Model Feasibility)}

Model reliability test or model feasibility test, or more popularly referred to as $\mathrm{F}$ test (Simultaneous test) is the initial stage of identifying the regression model that is estimated to be feasible or not. The intent of feasible is a model that is estimated to be worth using to explain the influence of free variables on bound variables. $F$ test results can be seen in the output result table above. Probability Value $F$ (statistic) of $0.000000<0.05$ or less than the significance level of 0.05 . So it can be concluded that the estimated regression model is feasible to be used to explain the influence of variable technological advances (X1), investment (X2), labor (X3) and education (X4) on GDP (Y).

\section{T Test (Regression Coefficient Test)}

T-tests in multiple linear regressions are intended to test whether parameters (regression coefficients and constants expected to estimate multiple linear regression model equations or models are correct or not. From the test results $t$ can be seen in the table of estimated output results. If the calculated probability value of $t$ is less than the error rate (alpha) of 0.05 then it can be said that a free variable has a significant effect on its bound variable. Whereas if the value of prob.t count is greater than the error rate of 0.05 . Thus, it means that the free variable has no significant effect on the bound variable.

Prob value T count of technological advancement variables is 0.0000 smaller than alpha value of 0.05 . So it can be interpreted that, free variables technological advances have a significant effect on variables bound to GDP at a confidence level of $95 \%$. Prob value T calculate of the investment variable 0.3831 is greater than the alpha value of 0.05 . In another meaning, investment-free variables have no significant effect on variables bound to GDP at a confidence level of $95 \%$. Prob value T count of the labor variable is 0.0000 smaller than the alpha value of 0.05 . The labor-free variables have a significant effect on variables bound to GDP at a confidence level of $95 \%$. Prob value. The T count of the education 
variable is 0.0000 smaller than the alpha value of 0.05 . In sum, the free variable education has a significant effect on the variable bound PDRB at a confidence level of $95 \%$.

\section{The Effect of Technological Advances on Economic Growth}

Based on the results of multiple regression estimates, it shows that variable technological advances have a positive and significant effect on GDP growth in central Java. The variable coefficient of technological advancement is 0.300264 . Technological advances have a significant positive effect on the central Java economic GDP. If technological advances rise by 1 percent, the growth of central Java GDP will increase by 0.30 percent. It proves that the advancement of technology in central Java has a significant influence on the growth of central Java GDP is significant.

The results of this study are in accordance with the macro theory. The endogenous growth theory explains that GNP growth is actually a natural consequence of long-term equilibrium. Endogenous growth theory has structural similarities to neoclassical theory, but differs greatly in terms of underlying assumptions and conclusions. A very significant theoretical difference stems from the release of neoclassical assumptions about declining marginal yields on capital investment, providing an opportunity for an increasing scale of yield in aggregate production and often focusing on the role of externalities in determining the rate of return on capital. It was assumed that public and private sector investment in human resources results in an external economy and increased productivity that reverses the natural downward trend in yields, endogenous growth theory seeks to explain the existence of increasing yield scales and different long-term growth patterns between countries. Since technology still plays an important role in this theory, it is no longer necessary to explain long-term economic growth (Todaro and Smith, 2006).

This study found that technological advances have a significant and positive influence on economic growth in Central Java in 2016-2020, this points that increasing technological advances will have an impact on improving economic growth. The findings are in line with research conducted by Ardi (2013), Lucya \&Anis (2019). Those research explained that technological advances have an influence on economic growth, this shows that the increase in economic growth is followed by a high level of technological advancement.

\section{The Effect of Investment on Economic Growth}

Based on the results of multiple regression estimates, it shows that the investment variables are negative and insignificant to GDP growth in central Java. The variable coefficient of investment is 1.19E-07 the investment negatively affects the central Java economic GDP insignificantly. If investment rises by 1 percent, then the growth of central Java GDP will decrease by -1.19 percent.

The results of this study found that investment has no significant effect on economic growth in Central Java Province in 2016-2020, this study identifies that in 2020 the government is experiencing the COVID-19 pandemic. this shows that economic growth data in 2020 is negative, so it can be identified that data in 2020 will have an aggregate impact on the results of data analysis. It has an impact on a very significant reduction in the level of investment. In addition, on the other hand, government spending is more focused on allocating funds as social assistance for each area affected by COVID-19. Having seen at the results of the analysis that the coefficient in the investment model showed a negative result, the result is in accordance with the findings of previous research conducted by Sulistiawati (2012), she explained that the negative coefficient has the meaning that investment in economic growth and has a movement that is not in the direction, the increase occuring in investment is followed by a decrease in economic growth and vice versa caused by the impact of the global economy crisis and the uneven spread of investment at the provincial level.

\section{The Impact of Labor on Economic Growth}

Based on the results of multiple regression estimates, shows that labor variables have a positive and significant effect on GDP growth in central Java. The variable coefficient of labor is 5.37E-05 workers have a significant positive effect on the central Java economic GDP. If the number of workers increases by 1 percent, then the growth of central Java GDP will increase by 5.37 percent. It happens to the 
number of high school graduates being relatively more than the college graduates. Thus, this variable contribution supports the increase of GDP in central Java.

This study found that the workforce has a significant and positive influence on economic growth in Central Java in 2016-2020, this indicates that the increase in labor will have an impact on improving economic growth. These findings are in line with research conducted by Nizar et al (2013); Lubis (2014). They explained that the labor has an influence on economic growth, this shows that the increase in economic growth is followed by an increased quantity of labor.

\section{The Effect of Education on Economic Growth}

Based on the results of multiple regression estimates, it shows that educational variables have a positive and significant effect on GDP growth in central Java. The variable coefficient of education is 0.588457 . The education significantly affects the GDP of central Java's economy. If the growth rate of educated people rises by 1 percent, then the growth of central Java GDP will increase by 0.58 percent. It proves that the contribution of education in central Java to the growth of central Java GDP is significant. This is in accordance with the research journal conducted by Nazamuddin faculty of economics, Syiah Kuala University, he said "Aceh education has a growing tendency, both in terms of quantity and quality. This is indicated by the high literacy rate, participation rate, and average length of school. In addition, there is a positive relationship between educational performance and economic growth, as indicated by increased economic growth, per capita income, and decreased unemployment. Although access to education in Aceh is relatively good, there are problems in terms of the quality of education, especially in terms of teacher quality and management of education unit management. Education spending is not directly related to the performance of education, but how education is managed from the level of management at the provincial and district levels to the school level determines the quality of educational output".

This is in accordance with the journal written by Ridwan Maulana and Prasetyo Ari Bowo in JEJAK Journal of Economics and Policy; Based on the results of the study, it is known that the number of workers who are educated in elementary school is decreasing while the workforce educated in junior high school and senior high school has increased. It shows that the increase in the average length of school in Central Java Province impact the quality of labor education better. The improvement in quality has an effect on the productivity of the energy that further encourages economic growth.

This study found that education has a significant and positive influence on economic growth in Central Java in 2016-2020. It indicate that increasing education have an impact on improving economic growth. The findings are in line with research conducted by Nugroho (2016); Lucya \&Anis (2019). They explained that education has an influence on economic growth, it shows that the increase in economic growth is followed by higher education.

\section{CONCLUSIONS}

Based on the analysis of data and discussions that have been described earlier, the results of this study can be concluded that the model on technological, labor and education advancements have a significant and positive influence on economic growth in Central Java in 2016-2020, The increasing of technological, labor and education advances are able to contribute to the improvement of economic growth in Central Java Province. While the variable on investment in Central Java Province in 20162020 has no significant influence on economic growth, consequently investment conditions in Central Java Province in 2016-2020 have no impact on improving economic growth. The results of this study identified that the investment variable is strongly influenced by the COVID-19 pandemic in 2020. The implications of government policies in improving economic growth and maintaining economic growth stability can be done through improving the quality and quantity of technological, labor and education advances.

\section{REFERENCES}

Agustini, Y., \& Kurniasih, E. P. (2017). Pengaruh Investasi PMDN, PMA, dan Penyerapan Tenaga Kerja Terhadap Pertumbuhan Ekonomi dan Jumlah Penduduk Miskin Kabupaten/Kota di Provinsi 
Kalimantan Barat. Jurnal Ekonomi Bisnis dan Kewirausahaan, 6(2), 97-119

Ardi, B. K. (2013). Pengaruh kemajuan teknologi informasi terhadap perkembangan sistem informasi akuntansi. Jurnal Ekonomi No, 38.

Arsyad, L.,1999. Pengantar Perencanaan dan Pembangunan Ekonomi Daerah.Yogyakarta:BPFE.

Aulia, M., \& Masbar, R. (2016). Analisis Efektifitas Penggunaan Cadangan Devisa Dan Financial Deepening Terhadap Stabilitas Nilai Tukar. Jurnal Ekonomi dan Kebijakan Publik Indonesia, $3(2), 78-92$.

Boediono, 1988.Ekonomi Moneter. Yogyakarta : BPFE.Cheng, Benjamin S and Tin Wei Lai (1997). Government Expenditures and Eco-nomicGrowthin South Korea: A VAR Approach, Journal of Economic Development.

BPS.2021. Jawa tengah Dalam Angka 2021.Semarang:BPS

Chandra, T. (2015). Analisis pertumbuhan ekonomi dan pengembangan sektor potensial di kota makassar. Jurnal lqtisaduna, 1(2), 79-99.

Dhani, T. P. T. N. H. (2016). Penerapan Model SOLOW-SWAN Untuk Memacu Pertumbuhan Ekonomi Kabupaten Demak. Media Ekonomi dan Manajemen, 30(1).

Diana, M., Susilowati, D., \& Hadi, S. (2017). Analisis sektor ekonomi unggulan di provinsi maluku utara. Jurnal IImu Ekonomi JIE, 1(4), 400-415.

Ernita, D., Amar, S., \& Syofyan, E. (2013). Analisis pertumbuhan ekonomi, investasi, dan konsumsi di Indonesia. Jurnal Kajian Ekonomi, 1(2).

Hapsari, I. (2018). Analisis Efisiensi Investasi Di Provinsi Sulawesi Tenggara Pada Periode 2001-2013. Mega Aktiva: Jurnal Ekonomi dan Manajemen, 6(1), 12-18.

Hardinandar, F. (2019). Determinan Kemiskinan (Studi Kasus 29 Kota/Kabupaten di Provinsi Papua). Jurnal REP (Riset Ekonomi Pembangunan), 4(1), 1-12.

Kementrian Koordinator Bidang Perekonomian. 2011. Masterplan Percepatan dan Perluasan Pembangunan Ekonomi Indonesia 2001-2025. Jakarta: Kemenko

Kuncoro, M,. 1977. Analisis Spasial dan Regional: Studi Aglomerasi dan Kalster Industri Indonesia. Yogyakarta: UPP AMP YKPN.

Lini, Z. Z., \& Sasana, H. (2019). Pengaruh Tingkat Globalisasi Terhadap Pengangguran Di ASEAN. Jurnal REP (Riset Ekonomi Pembangunan), 4(1), 13-26.

Lubis, C. A. B. E. (2014). Pengaruh jumlah tenaga kerja, tingkat pendidikan pekerja dan pengeluaran pendidikan terhadap pertumbuhan ekonomi. Jurnal Economia, 10(2), 187-193.

Lucya, C., \& Anis, A. (2019). Pengaruh Teknologi Dan Pendidikan Terhadap Pertumbuhan Ekonomi Di Indonesia. Jurnal Kajian Ekonomi dan Pembangunan, 1(2), 509-518.

Nizar, C., Hamzah, A., \& Syahnur, S. (2013). Pengaruh investasi dan tenaga kerja terhadap pertumbuhan ekonomi serta hubungannya terhadap tingkat kemiskinan di indonesia. Jurnal IImu Ekonomi ISSN, 2302, 172.

Nugroho, S. B. M. (2016). Pengaruh Pendidikan Terhadap Pertumbuhan Ekonomi. Media Ekonomi dan Manajemen, 29(2).

Purba, N. S., \& Darmawan, A. (2018). Pengaruh Pertumbuhan Produk Domestik Bruto Dan Inflasi Terhadap Non Performing Finance Bank Syariah (Studi Pada Bank Umum Syariah Di Indonesia Periode 2014-2016). Jurnal Administrasi Bisnis, 61(2), 161-167.

Rustiono, D. (2008). Analisis pengaruh investasi, tenaga kerja, dan pengeluaran pemerintah terhadap pertumbuhan ekonomi di Propinsi jawa tengah (Doctoral dissertation, program Pascasarjana Universitas Diponegoro).

Solow, R. M. (1956). A Contribution to the Theory of Economic Growth. The Quarterly Journal of Economics, 70 No.1(Feb.,1965), $65-94$.

Sulistiawati, R. (2012). Pengaruh investasi terhadap pertumbuhan Ekonomi dan penyerapan tenaga kerja serta kesejahteraan masyarakat di Provinsi di Indonesia. Jurnal ekonomi bisnis dan kewirausahaan, 3(1), 29-50.

Tarmizi, T. (2018). Analisis Kredit Usaha Terhadap Pertumbuhan Ekonomi Islam dan Konvensional. Jurnal Ekombis, 3(1).

Todaro, M. P. dan Smith, S. C.,2012. Economic Development, eleventh edition, Addision Wesley, 
Pearson

Todaro, M. P., 2000. Pembangunan Ekonomi Dunia Ketiga. Jakarta: BPFE UI 